\title{
О происхождении и эволюции вирусов по результатам исследований вирусоподобных микрофоссилий в кремнистых породах Палеопротерозоя, остров Гогланд, Финский залив
}

\author{
Беляев А.М. ${ }^{1}$, Юхалин П.В. ${ }^{2}$ \\ действительные члены Палеонтологического общества при РАН
}

${ }^{1}$ Санкт-Петербургский государственный университет, Институт наук о Земле, 199034, Университетская наб., 7/9.

Email: paleovirusology@mail.ru; a.beliaev@spbu.ru; abel-7-777@yandex.ru

https://orcid.org/0000-0001-7035-7521; http://www.paleovirusology.ru/

${ }^{2}$ Paleovirusology group, ООО Сидосе, Санкт-Петербург

Email: paleovirusology@mail.ru

Origin and Evolution of Viruses, Based on the Results Research of Virus-Like Microfossils in the Paleoproterozoic Siliceous Rocks, Hogland Island, Finland Gulf

$$
\text { Anatoly. M. Belyaev }{ }^{1,2 *} \text {, Paul V. Yukhalin }{ }^{2}
$$

\author{
${ }^{1}$ Institute of Earth sciences, St. Petersburg State University, St. Petersburg, Russia \\ Email: paleovirusology@mail.ru; a.beliaev@spbu.ru; abel-7-777@yandex.ru \\ 2 Paleovirusology group, Sidose LLC, St. Petersburg, Russia \\ Email: paleovirusology@mail.ru
}

Summary

Virus-like microfossils in the 1.64 Ga Siliceous Rocks from Hogland Island, Russia were inspected. They are similar in morphology to modern giant viruses of the family Mimiviridae, but exceed them in linear size by a thousand times or more. In addition, virus-like microfossils contain structures similar to eukaryotic nuclei, and apatite grains that may have crystallized from phosphoric acid residues of decayed nucleotides. The genome masses of microfossils of viruslike structures, estimated both by the included apatite grains and by the size of the nuclei (in accordance with the principle of genomic-nuclear proportionality), averaged tens of thousands of picograms and, accordingly, could contain tens of thousands of billions of nucleotide pairs.

It is assumed that the microfossils of virus-like structures from the group of unclear systematic position Dinoviridae Incertae sedis were representatives of an extinct family of singlecelled facultative parasites, or were the ancestors of giant viruses of the family Mimiviridae.

Keywords: viruses, eukaryotic genomes, Paleoproterozoic microfossils, siliceous rocks, carbon isotopes, underwater volcanism

Аннотация

Несколько разновидностей вирусоподобных микрофоссилий, близких по морфологии к современным гигантским вирусам семейства Mimiviridae были выявлены в микрокварцитах в составе вулканогенно-осадочных толщ с возрастом 1640 миллионов лет на острове Гогланд в Финском заливе, Россия. Микрокварциты содержат графит, 
обогащенный лёгким изотопом углерода ${ }^{12} \mathrm{C}$, как это характерно для пород, образовавшихся с участием живого вещества. Многочисленные останки окремненных и ожелезненных микрофоссилий планктонных микроорганизмов и вирусоподобных структур были найдены во фрагментах окремненных биопленок. Однако, вирусоподобные микрофоссилии превышают современные гигантские вирусы по линейным размерам в тысячу раз и более (Belyaev, 2018; 2019; Belyaev, Yukhalin, 2021), и содержат структуры подобные ядрам эукариотов. Кроме того, получены данные, которые могут быть истолкованы как факт паразитических взаимоотношений вирусоподобных образований с клетками древних амебообразных микроорганизмов. Внутри, и в непосредственном окружении некоторых вирусоподобных структур, наблюдаются мелкие овальные зональные образования, которые, возможно, представляют собой окремненные вирусные частицы, древнейших облигатных сверхпаразитов, подобных вирофагам «Спутник»у мимивирусов (La Scola, et al., 2008). Зерна апатита, обнаруженные в минерализованной цитоплазме и ядрах вирусоподобных микрофоссилий, скорее всего, кристаллизовались из остатков фосфорной кислоты распавшихся нуклеотидов. Это позволило впервые приблизительно оценить величину геномов древнейших вирусоподобных структур, которые превышали геномы современных гигантских вирусов и одноклеточных организмов в тысячи раз (Belyaev, Yukhalin, 2021). Массы геномов микрофоссилий эукариотов и вирусоподобных структур были также оценены в соответствии с принципом геномно-ядерной пропорциональности, согласно которому молекулярные массы геномов прямо пропорциональны размерам ядер. При этом размеры геномов вирусоподобных структур, оцененные как по включенным зернам апатита, так и по величине ядер, в среднем составили десятки тысяч пикограмм и, соответственно, могли содержать десятки тысяч миллиардов пар нуклеотидов. Предполагается, что микрофоссилии вирусоподобных структур из группы неясного систематического положения Dinoviridae Incertae sedis были представителями вымершего семейства одноклеточных факультативных паразитов, либо являлись предками гигантских вирусов семейства Mimiviridae.

Ключевые слова: вирусы, геномы эукариотов, микрофоссилии палеопротерозоя, кремнистые породы, изотопы углерода, подводный вулканизм

\section{Введение}

Изучение происхождения и эволюции вирусов особенно актуально в связи с общемировой пандемией, затронувшей практически все человечество. Каждый житель Земли имел неоднократные контакты и постоянные проблемы, связанные с этими представителями живого мира. Вирусы поражают все виды клеток, и являются самой многочисленной биологической формой на Земле (Canchaya et al., 2003). Возможно, что вирусные пандемии приводили к вымиранию многих видов живых организмов, и, тем самым, влияли на ход эволюции биосферы. Кроме того, предполагается, что вирусы являлись важным естественным средством переноса генов между различными видами, способствовали их эволюции и генетическому разнообразию (Canchaya et al., 2003).

Согласно современным гипотезам вирусы могли возникнуть одновременно с живыми организмами, или произойти от плазмид - частиц нуклеотидов, которые имели возможность перемещаться между клетками. Вирусы могли появиться в процессе эволюции мелких клеток факультативных паразитов, которые со временем утратили возможность самостоятельного размножения, и превратились в облигатных паразитов вирусы (Legendre, 2012). Морфологическое и генетическое разнообразие вирусов предполагает, что в прошлом они могли образоваться разными независимыми способами.

Вирусы демонстрируют огромное разнообразие форм и размеров. Зрелые частицы оболочечных вирусов содержат нуклеиновые кислоты, заключенные в белковые 
оболочки - капсиды. Среди них встречаются как простые спиральные и сферические структуры, так и более сложные, в виде икосаэдров. Большая часть изученных в XX веке вирусов имеют размеры в пределах от 20 до $300 \mathrm{Hм}\left(1 \mathrm{Hм}=10^{-12} \mathrm{~cm}\right)$. Однако, в последние десятилетия были найдены несколько видов гигантских вирусов семейства Mimiviridae (Abergel, et al., 2015; Arslan, et al., 2011; Jônatas Abrahão, et al., 2018). Они превосходят традиционные вирусы по линейным размерам в десятки и сотни раз. Мимивирусы, Мегавирусы и Тупанвирусы, имеют капсиды, близкие по форме к двадцатигранникам икосаэдрам, и в сечениях наблюдаются как шестигранные или пятигранные зональные структуры. У Тупанвирусов есть также длинный «хвост» (Jônatas Abrahão et al., 2018). Геномы Mimiviridae включают как ДНК, так и РНК и от одного до полутора миллионов пар оснований, которые, соответственно, имеют массы около миллиона и более пикограмм (нуклеотид массой в 1 пг содержит 978 миллионов пар оснований). Предполагается, что предки гигантских вирусов могли иметь клеточное строение, и способность к самостоятельному размножению. Так, первооткрыватели гигантских Тупанвирусов допускают, что они произошли от более сложных одноклеточных организмов, которые в процессе перехода к паразитическому образу жизни утратили возможность самостоятельного размножения и потеряли часть генов (Legendre, et al., 2012; Abergel, et al., 2015; Jônatas Abrah ão, et al., 2018).

Однако, несмотря на многообразие и разнообразие вирусов и той роли, которую они сыграли в эволюции биосферы, их генезис не ясен, так как окаменевшие останки вирусов до сих пор не были обнаружены в горных породах, и даже в современных осадках. Отсутствие окаменевших останков вирусов связано с тем, что по существу, они представляют собой крошечные белковые капсулы, которые после гибели испытывают постмортальные преобразования - лизис (растворение) или коллапс. Вместе с тем, имеются данные об экспериментальном окремнении вирусов. Белки и икосаэдрические капсиды головок бактериофагов Т4 замещаются кремнеземом, который проникает и осаждается в различных вирусных структурах (Laidler, et al., 2010). Эти исследования предполагают, что окремненные микрофоссилии вирусов могут быть обнаружены в горных породах.

\section{1. Условия фоссилизации вирусоподобных структур в кремнистых породах острова Гогланд}

Бесскелетные микроорганизмы лучше всего сохраняются в кремнистых породах, образовавшихся из горячих, насыщенных кремнекислотой вод. Такие породы известны около современных термальных источников (Westall, et al., 1995; Benning, et al., 2002), а также в составе вулканогенно-осадочных толщ (Belyaev, 2018; Belyaev, 2019; Belyaev, Yukhalin, 2021).

Внутри кремнистых пород (микрокварцитов), залегающих среди лавовых покровов базальтов и риолитов на острове Гогланд в Финском заливе были впервые найдены шестигранные вирусоподобные структуры в ассоциации с микрофоссилиями планктонных прокариотов и эукариотов. Ранее, геологическими исследованиями было установлено, что покровы базальтов и риолитов сформировались в условиях подводных извержений в континентальном морском бассейне (море Абеля), о чем свидетельствуют характерные для таких обстановок подушечные структуры в лавах (Belyaev, et al., 1998; Belyaev, 2018; Belyaev, Yukhalin, 2021). U-Pb изохронное датирование цирконов из риолитов составило $1638 \pm 4$ и $1640 \pm 11$ миллионов лет (Belyaev, et al., 1998), что совпадает с возрастом 1640 миллионов лет гранитов Выборгского комплекса рапакиви (Ларин, 2011). Были также получены геохимические свидетельства существенного обогащения морской воды калием, 
за счет ювенильных флюидов, отщепленных от щелочной базальтовой и рапакивигранитной магм (Belyaev, 2013; Belyaev, 2018).

Кремнистые породы в виде линзовидных прослоев среди покровов базальтов и риолитов сформировались в процессах взаимодействия магматических расплавов с морской водой. Излившиеся раскаленные магмы нагревали придонные воды до высоких температур, и насыщали их ионами двухвалентного железа, а на поверхности потоков происходило интенсивное растворение оксидов кремния. После подъема нагретой воды с пониженной плотностью в верхние горизонты морского бассейна и ее охлаждения образовывался гель кремнекислоты. Он осаждался и накапливался в углублениях палеорельефа на застывших вулканических породах, часто окаймляя подушечные структуры. Темные прослои в микрокварцитах, обогащенные эпидотом, образовались при метаморфизме частичек вулканического стекла пеплового материала (Рис. 1.1.). Под воздействием тепла перекрывающих лавовых потоков кремнистые осадки претерпели контактовый метаморфизм, превратившись в микрокварциты, сложенные мелкими кристаллами кварца, хлорита и эпидота. Глинистые осадки превратились в серицитовые сланцы, состоящие из мелкозернистой калиевой слюды серицита (Belyaev, 2018; Belyaev, Yukhalin, 2021).

Придонные воды, нагретые лавами и насыщенные оксидами кремния и ионами железа поднимались в приповерхностные горизонты бассейна, где они приводили к быстрой фоссилизации (окремнению и ожелезнению) планктонного сообщества микроорганизмов вместе со слизистой субстанцией, в которой они сосуществовали. Оксиды кремния из минерализованного раствора проникали внутрь микроорганизмов, и замещали цитоплазму и органеллы опалом или коллоидным гелем кремнекислоты, а гидроокислы железа, осаждались на стенках мембран и перегородок, или образовывали коллоидный гель, замещающий цитоплазму. Фрагменты минерализованных бактериальных пленок и отдельные микрофоссилии окремненных и ожелезненных микроорганизмов оседали на дно, и погружались в кремнистые и глинистые осадки, вместе с которыми претерпели контактовый метаморфизм.

2. Исследования изотопного состава углерода из микрокварцитов были проведены в Центре изотопных исследований Российского геологического исследовательского института на элементарном анализаторе Flash EA 1112 (ThermoQuest, Milano, Italy), multicollector mass-spectrometer DELTA ${ }^{\text {Plus }}$-XL (ThermoFinnigan, Germany) c газовым коммуникатором ConFlo III (ThermoFinnigan, Germany). Результаты четырех измерений показали, что в микрокварцитах из базальтов и риолитов содержится графит, обогащенный легким изотопом ${ }^{12} \mathrm{C}\left(\delta^{13} \mathrm{C}=-27.1--29.5 \%\right)$. Это указывает на присутствие органического вещества биогенного происхождения в кремнистых породах острова Гогланд, которое, очевидно, связано с присутствием остатков планктонных микроорганизмов (Belyaev, 2018; Belyaev, Yukhalin, 2021).

\section{3. Микроскопические исследования}

Микрокварциты в базальтах и риолитах содержат многочисленные останки окремненных и ожелезненных микрофоссилий планктонных микроорганизмов прокариотов и эукариотов, подобных по морфологии современным коккоидным и спиралевидным цианобактериям, амебам, диатомеям, фораминиферам, жгутиконосцам и многоклеточным организмам, которые до сих пор не были известны в породах палеопротерозойского возраста. Их описание и микрофотографии представлены в ранее опубликованных работах (Belyaev, 2018; Belyaev, 2019; Belyaev, Yukhalin, 2021). Следует отметить весьма важное обстоятельство, что обнаруженные микрофоссилии представляют 
собой псевдоморфозы замещения, образовавшиеся одновременно с вулканическими породами 1640 миллионов лет тому назад. Хорошо сохранившиеся контуры микрофоссилий, их внутренняя структура и, главное, ненарушенное взаимное расположение микроорганизмов в микрокварцитах и серицитовых сланцах, указывают на то, что их фоссилизация (окремнение и ожелезнение) происходила по окружавшей слизистой субстанции (биопленке). Поэтому возможно изучать не только особенности строения древних микроорганизмов, но и их пространственные взаимоотношения в экосистеме планктонных сообществ.

\section{4. Вирусоподобные структуры в микрокварцитах острова Гогланд}

Микрофоссилии древних микроорганизмов, обладавших внешними белковыми оболочками в виде многогранников, впервые были найдены в микрокварцитах в тесной ассоциации с останками окремненных и ожелезненных микрофоссилий прокариотов и эукариотов (Belyaev, 2018). Многогранные структуры подобны по морфологии современным гигантским вирусам семейства Mimiviridae, и рассматриваются нами как вирусоподобные VS. Также получены данные, которые могут быть истолкованы как факт паразитических взаимоотношений вирусоподобных образований с микрофоссилиями амебообразных микроорганизмов. Однако такие признаки наблюдаются не во всех сечениях геологических препаратов. Поэтому к вирусоподобным структурам условно отнесены микрофоссилии с шестигранными и пятигранными внешними контурами, которые, возможно, являются сечениями икосаэдрических внешних оболочек. Вместе с тем ископаемые вирусоподобные структуры превосходят современные гигантские вирусы по линейным размерам в тысячу раз и более. Кроме того, эти микрофоссилии имеют признаки клеточного строения и деления, тогда как, по определению, вирусами могут называться образования, не имеющие клеточного строения, и способные к размножению только в клетках живых организмов. Поэтому в данной работе найденные структуры рассматриваются как вирусоподобные в составе группы неясного систематического положения (Incertae sedis) с предварительным названием Dinoviridae (Belyaev, 2018; Belyaev, Yukhalin, 2021).

\section{1. Вирусоподобные структуры в микрокварцитах среди базальтов}

Микрокварциты среди базальтов сформировались в результате контактового метаморфизма: 1) кремнистых осадков - Mk (Рис. 1.1); 2) окремненного слизистого вещества биопленок - Mk-1 (Рис. 1.2); 3) окремненной цитоплазмы микроорганизмов и окружающего клетки слизистого вещества - Mk-0 (Рис. 1.2-1.5). В петрографических шлифах из микрокварцитов были обнаружены шестиугольные зональные образования, внутренние и внешние контуры которых сложены цепочками мелких зерен гематита (Hem). Мозаичные структуры микрокварцитов (Mk-0) внутри контуров и в окружающей основной массе подобны (Рис. 1.2.), что указывает на их одновременное формирование в близких физико-химических условиях. Шестиугольные зональные структуры, возможно, являются сечениями икосаэдрических оболочек древних вирусоподобных образований. Зерна гематита, слагающие контуры, скорее всего, образовались в процессах перекристаллизации гидроокислов железа, адсорбированных на поверхности мембран (Рис. 1.2.-1.5.). Среди вирусоподобных образований встречаются также «сморщенные» зональные образования, которые, быть может, представляют собой псевдоморфозы по останкам погибших вирусоподобных структур (Рис. 1.3.). 


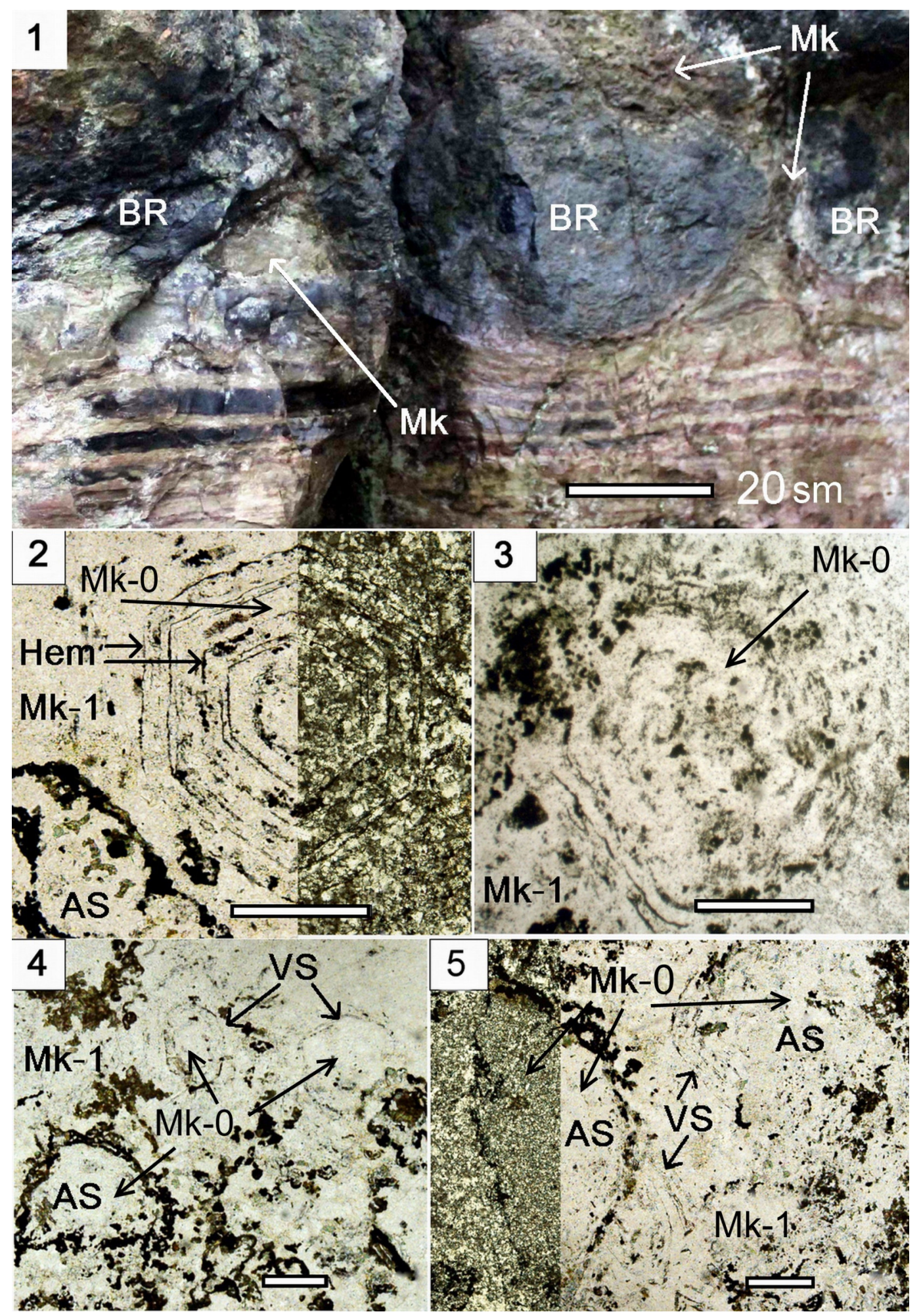

Рис. 1. Вирусоподобные структуры (VS) из микрокварцитов (Mk) в базальтах.

Масштабная линейка - 0.5 мм (500 мкм).

1.1. Подушки базальтовых лав (basaltic rocks - BR), залегающие на полосчатых микрокварцитах $(\mathrm{Mk})$, и окруженные микрокварцитом (Mk) 
1.2. Шестигранная зональная VS в микрокварцитах с внешними и внутренними контурами, сложенными цепочками зерен гематита (Неm). Слева внизу фрагмент амебообразной структуры (AS). Шлиф. Слева - без анализатора, справа - с анализатором.

1.3. «Сморщенная» VS в микрокварцитах - погибший вирус? Шлиф, без анализатора.

1.4. Две VS в микрокварцитах базальтов в ассоциации с амебообразной структурой (AS). Шлиф, без анализатора. 1.5. Фрагменты контуров зональных вирусоподобных структур (VS) в контакте с амебообразными структурами (AS). Шлиф, слева - с анализатором, справа - без анализатора.

Древние вирусоподобные образования находились в тесной ассоциации со структурами, которые с определенной степенью вероятности можно рассматривать как микрофоссилии амеб - AS (Рис. $1.2 ; 1.4 ; 1.5$.$) . Эти структуры имеют удлиненные или$ округлые внешние контуры (0.5 - 2 мм в поперечнике), и сложены цепочками зерен гематита, эпидота, хлорита и графита. Возможно, минералы оболочки сформировались при метаморфизме частиц, из которых древние амебы строили агглютинированные раковины.

Встречаются фрагменты зональных вирусоподобных структур (VS), которые находятся в непосредственном контакте с микрофоссилиями амеб (Рис. 1.5). Возможно, это псевдоморфозы по остаткам белкового вещества оболочек древних вирусоподобных структур, оставшихся, после их внедрения в клетки.

В микрокварцитах базальтов в тесной ассоциации с зональными вирусоподобными образованиями находятся не только амебообразные структуры, но и многочисленные псевдоморфозы, морфологически близкие к современным спиральным и коккоидным цианобактериям, и эукариотам - диатомовым водорослям и фораминиферам (Belyaev, 2018). Скорее всего, окремнение и ожелезнение планктонных микроорганизмов происходило совместно с биопленкой, в которой они сосуществовали.

\section{2. Вирусоподобные структуры в микрокварцитах из риолитовых лав}

Микрокварциты в риолитовых лавах присутствуют как в виде маломощных линз, хемогенных кремнистых осадков, так и в цементе эруптивных брекчий в ассоциации с серицитовыми сланцами (sericite slate - SS). Микрокварциты сформировались как по кремнистым осадкам, так по окремненному веществу биопленок - Mk-1. В этом случае в них наблюдается волнисто-струйчатая текстура, выраженная в переплетении полос различных оттенков, часто облекающих окремненные микрофоссилии цианобактерий и эукариотов (Mk-0), (Рис. 2.1). Микрокварциты Mk-1 имеют характерный красноватобурый цвет за счет мельчайших примесей окислов железа (Рис. 2.1; 2.2). Окремненная цитоплазма планктонных микроорганизмов также замещена микрокварцитом (Mk-0).

Серицитовые сланцы сложены мелкими чешуйками слюды серицита (Рис. 2.2; 2.3; $2,4)$, которые образовались при метаморфизме гидрослюд глинистых осадков. 

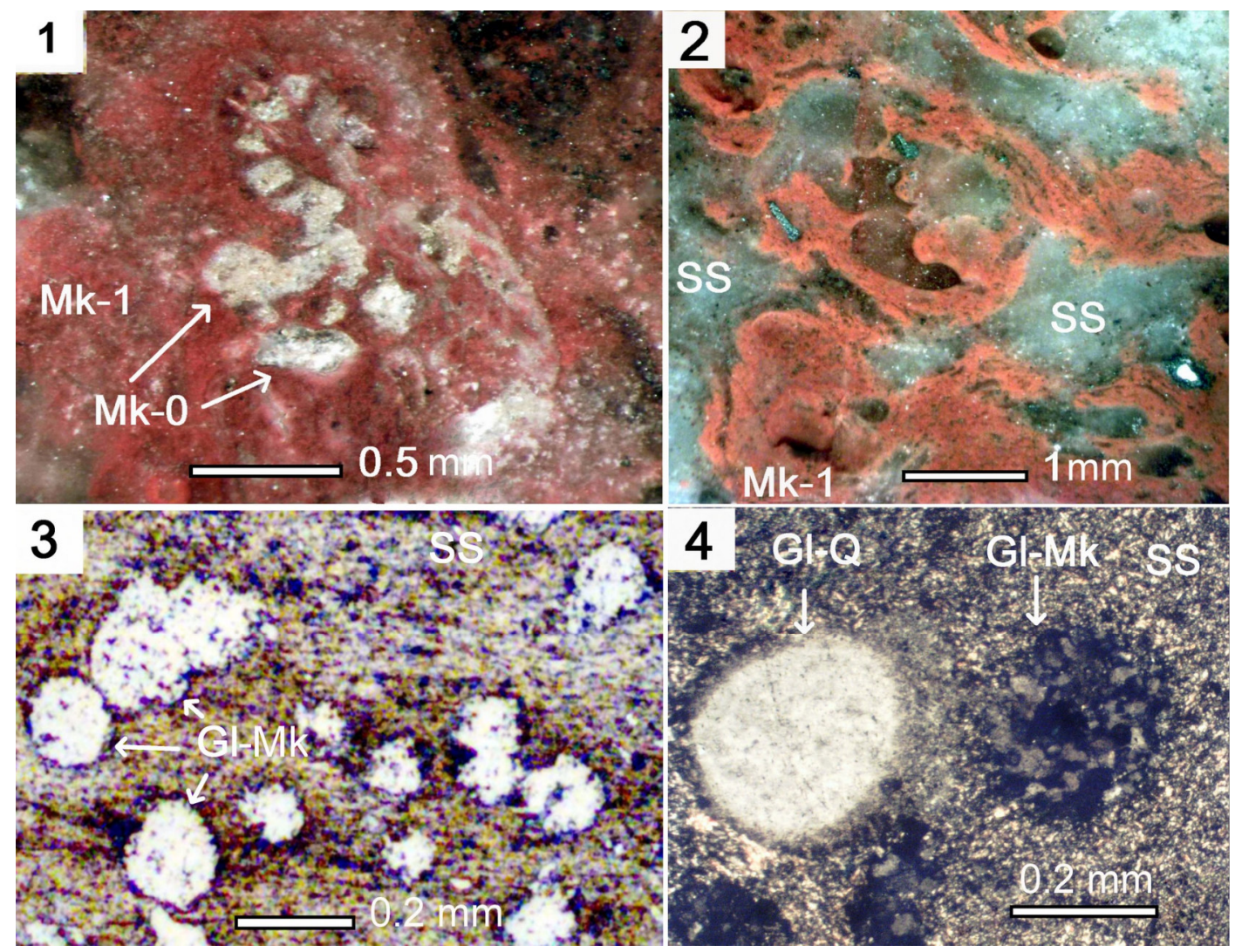

Рис. 2. Микрокварциты, серицитовые сланцы и вирусоподобные структуры

2.1. Микрокварцит по окремненному слизистому веществу биопленок (Mk_1), окружающий трихому цианобактерии (Mk_0). Аншлиф.

2.2 Фрагменты микрокварцитов с волнисто-струйчатой текстурой (Mk_1) в серицитовом сланце SS. Аншлиф.

2.3. Фрагмент, демонстрирующий текстуру серицитового сланца (SS), с глобулами (Gl). Прозрачно полированный шлиф без анализатора.

2.4. Округлые глобулы (Gl) кварца и микрокварцита в серицитовом сланце (SS). Шлиф, в проходящем свете, с анализатором.

В серицитовых сланцах и микрокварцитах, образовавшихся по окремненному слизистому веществу биопленок (Mk-1), присутствуют многочисленные инородные включения - округлые глобулы (globules - Gl) до 0.5 мм в поперечнике. Они представлены окатанными зернами кварца, с равномерным угасанием, характерным для кварца из гранитов рапакиви, и округлыми шариками микрокварцитов, в которых кварц имеет волнистое (облачное) угасание, характерное для динамо-метаморфических пород (Рис. 2.3; 2.4). Скорее всего, глобулы были мелкими окатанными песчинками, привнесенными в морские осадки древними песчаными бурями (Belyaev, 2018; Belyaev, Yukhalin, 2021).

В микрокварцитах $\mathrm{Mk}-1$, и в серицитовых сланцах встречаются несколько разновидностей шестигранных или пятигранных структур, различающихся размерами, внутренним строением и минеральным составом псевдоморфоз. Возможно, эти микрофоссилии представляли собой различные виды древних микроорганизмов, обладавших внешними белковыми оболочками в виде многогранников с икосаэдрической симметрией. Они ассоциируют с окремненными и ожелезненными микрофоссилиями амеб, цианобактерий, диатомей, фораминифер, жгутиконосцев и многоклеточных 
организмов (Belyaev, 2018). Внутри контуров вирусоподобные структуры сложены микрокварцитом (Mk-0), образовавшимся при окремнении внутриклеточной цитоплазмы или кварц-гематитовым агрегатом (quartz-hematite - Q-Hem), содержащим от 10 до 30\% зерен гематита. Кварц-гематитовый агрегат имеет специфическую симплектитовую структуру срастания двух минеральных фаз, сформированных в результате одновременной кристаллизации кремнистого геля и коллоидного раствора гидратов железа. Практически все вирусоподобные структуры окружены оболочками из микрокварцитов (Mk-0), которые образовались по окремненным слизистым оболочкам клеток (Belyaev, 2018).

Так, пятигранная зональная вирусоподобная структура (VS) в серицитовом сланце (SS) ассоциирует с глобулам-песчинками (Gl) микрокварцита (Рис. 3.1). Она имеет центральное округлое образование, сложенное кварц-гематитовым агрегатом (Q-Hem), окруженное зоной бурого микрокварцита с редкими вкрапленниками гематита. VS также окаймляется зоной светлого микрокварцита (Mk-0), образовавшегося при окремнении внешней слизистой оболочки клетки. Встречаются и более крупные по размеру шестигранные структуры 1х1.5 мм (Рис. 3.2), сложенные кварц-гематитовым агрегатом (Q$\mathrm{Hem})$, и окруженные оболочкой розового микрокварцита (Mk-0). Эта структура имеет хорошо выраженное округлое образование подобное ядру 0.18 мм в поперечнике, замещенное гематитом. В некоторых случаях отмечаются VS сложной формы, окаймленные оболочкой розового микрокварцита (Mk-0), которые, возможно, демонстрируют начало клеточного «деления» (Рис. 3.3).
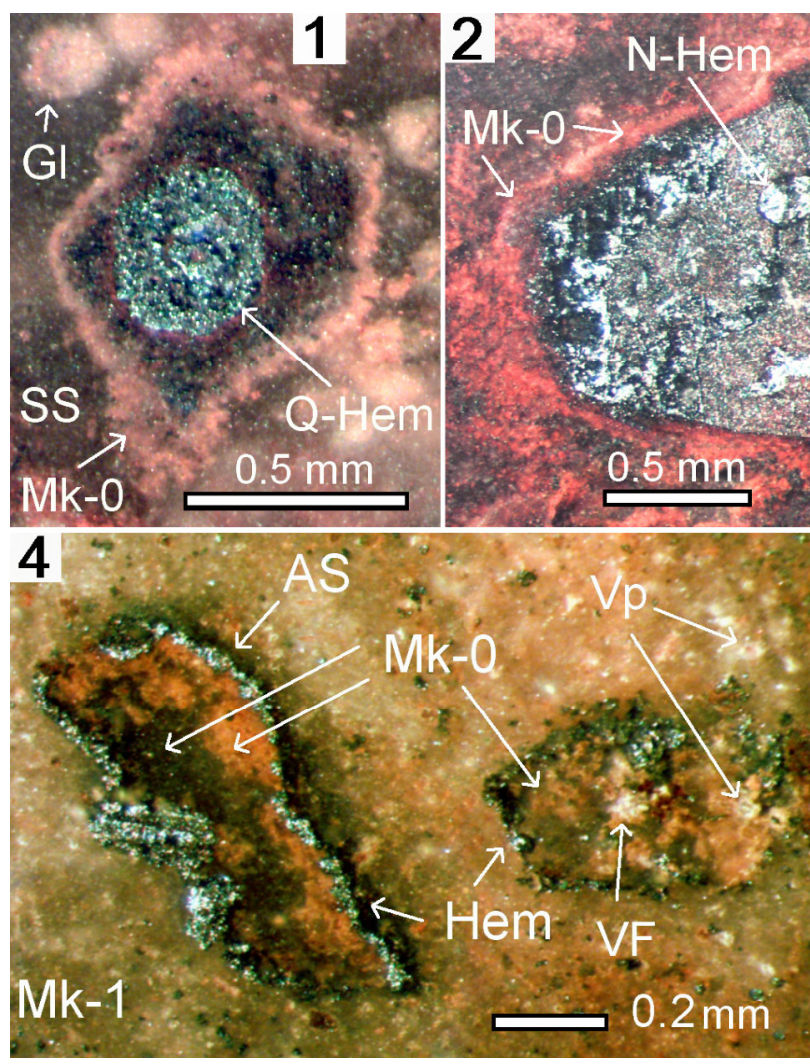
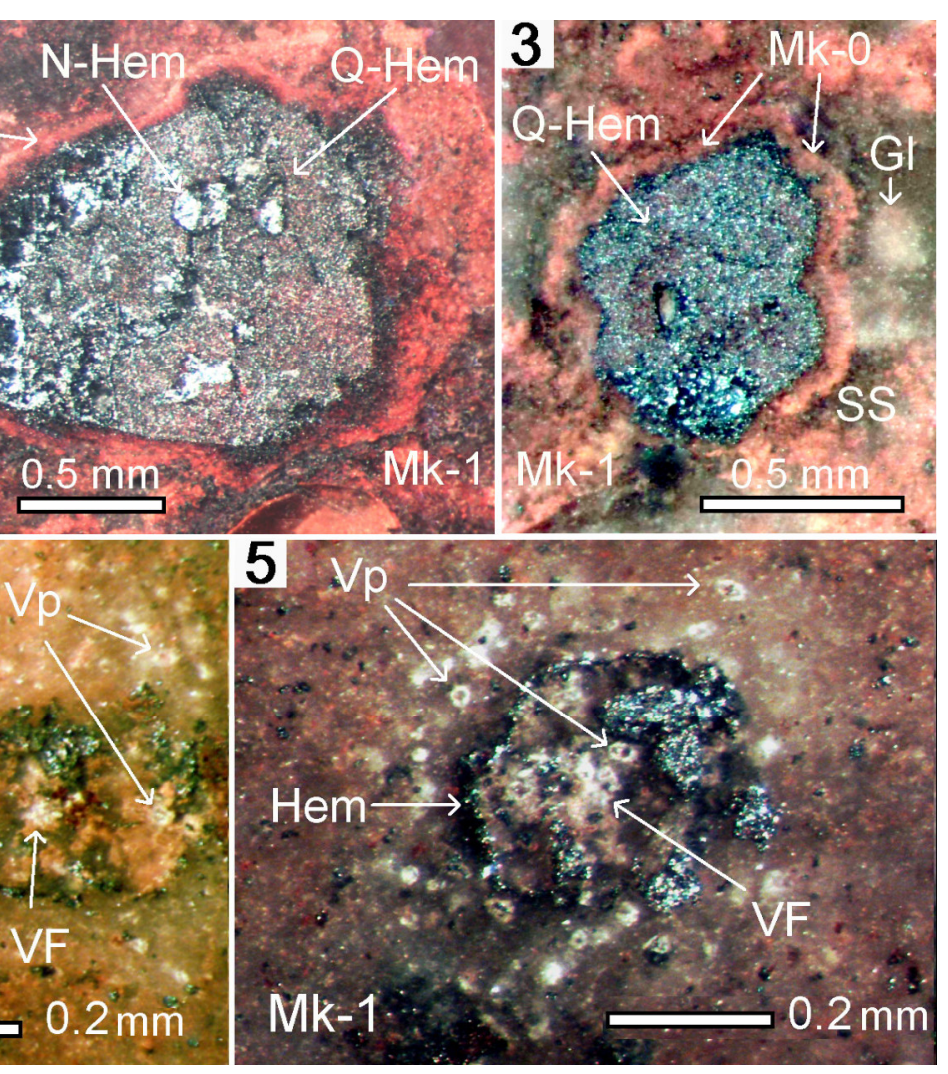

Рис. 3. Вирусоподобные структуры (VS), в микрокварцитах (Mk-1) и серицитовых сланцах (SS) из риолитов. Аншлифы, без анализатора. Масштабная линейка - 0.5 мм (500 мкм). 
3.1. Пятигранная зональная VS структура в серицитовом сланце (SS), окруженная микрокварцитом по кремнистой оболочке. Центральная часть сложена кварц-гематитовым агрегатом (Q-Hеm). Слева вверху глобулы-песчинки (Gl).

3.2. Шестигранная VS структура в микрокварцитах (Mk-1) сложенная кварцгематитовым агрегатом (Q-Hеm), и окруженная микрокварцитом по кремнистой оболочке $(\mathrm{Mk}-0)$. В верхней части видно отчетливо выраженное округлое образование, подобное ядру, сложенное гематитом (Неm).

3.3. VS сложной формы, в микрокварцитах (Mk-1) и серицитовом сланце (SS), окруженная микрокварцитом по кремнистой оболочке (Mk-0). Возможно, это начало клеточного «деления».

3.4. Вирусоподобная структура VS в ассоциации с амебообразной структурой (AS) в микрокварцитах (Mk_1). Контуры микрофоссилий сложены цепочками зерен гематита. Внутри VS и в ее окружении овальные зональные образования подобные вирофагам (Vp), сложенные светло-серым тонкозернистым микрокварцитом. В центре VS образование, подобное «вирусной фабрике» (VF).

3.5. Шестигранное сечение VS с контурами, сложенными цепочками зерен гематита. Внутри структуры и в ее окружении овальные зональные образования подобные вирофагам (Vp). В центральной части образование подобное «вирусной фабрике»-VF.

Вирусоподобные шестигранные структуры в микрокварцитах (Mk-1), часто ассоциируют с амебообразными структурами (AS) (Рис. 3.4). Контуры микрофоссилий сложены цепочками мелких зерен гематита (Hem), которые образовались, скорее всего, при кристаллизации гидроокислов железа, адсорбированных на поверхности оболочек и мембран. Овальные зональные образования (до 0.01 мм), сложенные светло-серым тонкозернистым микрокварцитом, наблюдаются внутри, и в непосредственном окружении вирусоподобных структур (Рис. 3.4.; 3.5.). Возможно, это окремненные вирусные частицы, древнейших облигатных сверхпаразитов, подобных вирофагам «Спутник» (virophage Sputnik - Vp), сосуществующих с Мимивируами (La Scola, et al., 2008).

\section{3. Микрофоссилии вирусоподобных структур в ассоциации с многоклеточными микроорганизмами}

Многоклеточными называются организмы, состоящие из двух и более специализированных видов клеток, которые возникают в результате деления материнских клеток. Но, в начальной стадии деления образуется только один тип клеток, называемых бластомерами. В микрокварцитах и серицитовом агрегате присутствуют структуры, которые могут быть интерпретированы как микрофоссилии клеток-бластомеров многоклеточных микроорганизмов (microfossils of multicellular microorganisms - MMM). Они представлены линейно вытянутыми (Рис. 4.1; 4.2), или ромбовидными четырехклеточными структурами (Рис. 4.3). Одна из линейных MMМ непосредственно контактирует с шестигранной вирусоподобной структурой VS, внутри которой есть округлое образование, подобное ядру (Рис. 4.1). Снаружи MMM и VS окружены общей кремнистой оболочкой. Возможно, что это вирусоподобная структура «напала» на многоклеточную структуру. Или наоборот, древнейшее многоклеточное животноехищник «напало» на вирусоподобную клетку эукариота. 

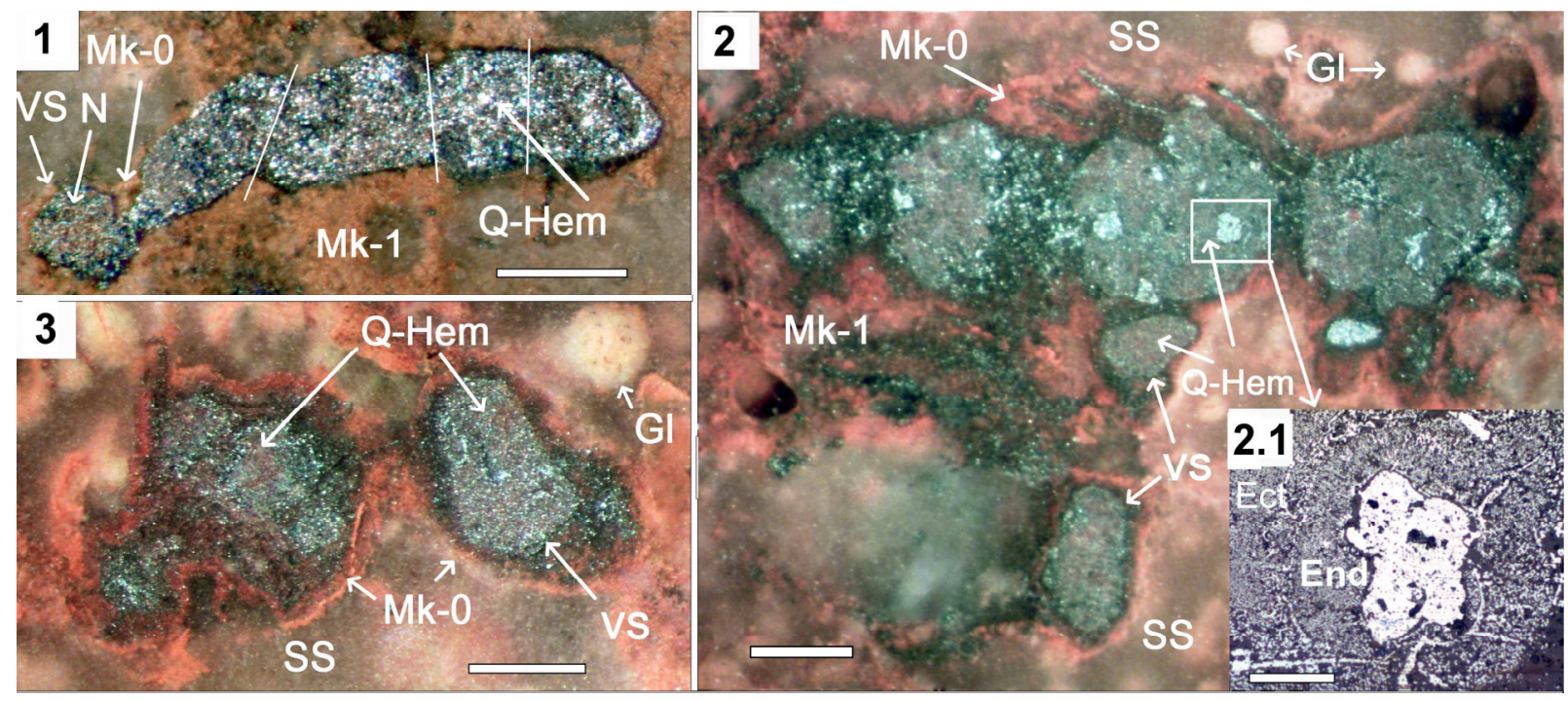

Рис. 4. Микрофоссилии вирусоподобных структур в ассоциации с многоклеточными микроорганизмами. Масштабная линейка -0.5 мм.

4.1. Линейно вытянутая четырех секционная MММ в микрокварците, в контакте с продолговатой шестигранной VS (слева). Внутри VS находится округлое образование типа ядра $(\mathrm{N})$.

4.2. Линейно вытянутая четырехклеточная MММ в серицитовом сланце (SS), сложенная кварц-гематитовым агрегатом (Q-Hem), и окруженная микрокварцитом по кремнистой оболочке (Mk-0). В центральной «клетке» два округлых образования, подобных ядрам, сложенные гематитом (Hem). В ассоциации с МММ три продолговатых шестигранных VS, сложенные кварц-гематитовым агрегатом (Q-Hem). В серицитовом сланце (SS) присутствуют глобулы-песчинки.

4.2.1. Образование типа ядра в одной из клеток, сложенное гематитом. Оно окружено двумя зонами, сложенными кварц-гематитовым агрегатом (Q-Hem) с симплектитовой структурой, сформировавшимся по эндоплазме (End) и эктоплазме (Ect) клетки. Светлоcерое - гематит, темно-серое - кварц. В отраженном свете с анализатором. Линейка 100 мКм.

4.3. Ромбовидная МММ в серицитовом сланце (SS) в ассоциации с продолговатой шестигранной VS. Обе структуры сложены кварц-гематитовым агрегатом (Q-Hem) и окружены микрокварцитом (Mk_0). Справа вверху присутствует глобула (Gl) микрокварцита.

Внутренние части МММ сложены кварц-гематитовым агрегатом с симплектитовой структурой. В одной из «клеток» МММ (Рис. 4.2.) наблюдается, замещенное гематитом, образование типа ядра. Оно окружено кварц-гематитовым агрегатом (Q-Hem) с симплектитовой структурой, в котором наблюдаются две отчетливые зоны, сформировавшимся, вероятно, по эндоплазме (End) и эктоплазме (Ect) клетки. (Рис. 4.2.1). В непосредственном контакте с МММ встречаются продолговатые шестигранные вирусоподобные структуры (продолговатыми называют икосаэдрические капсиды вирусов, вытянутые вдоль оси симметрии пятого порядка) (Рис. 4.2.; 4.3.). Вирусоподобные структуры также сложены кварц-гематитовым агрегатом (Q-Hem) с симплектитовой структурой. Ромбовидная MMM в серицитовом сланце (Ser) окружена кремнистой оболочкой совместно с продолговатой шестигранной VS. Справа вверху присутствует глобула (Gl) микрокварцита (Рис. 4.3). 


\section{4. Вирусоподобные структуры с «хвостами»}

Некоторые разновидности VS с шестигранными контурами (предположительно, сечениями белковых оболочек с икосаэдрической симметрией) имеют мешковидные образования «хвосты» - (tail - Tl), вместе с которыми они окружены кремнистыми оболочками (Рис. $5.1 ; 5.2 ; 5.3 ; 5.4$ ). По морфологии и размерам «капсидов» их можно разделить на две группы: крупные вирусоподобные структуры 0.8-1 мм в поперечнике, сложенные кварц-гематитовым агрегатом с симплектитовой структурой (Рис. $5.1 ; 5.2$ ), и средние вирусоподобные структуры с размерами 0.5 мм в поперечнике (Рис. $5.3 ; 5.4$ ). Средние VS предварительно отнесены к одному виду с условным названием Dinovirus hoglandi (D.h.).
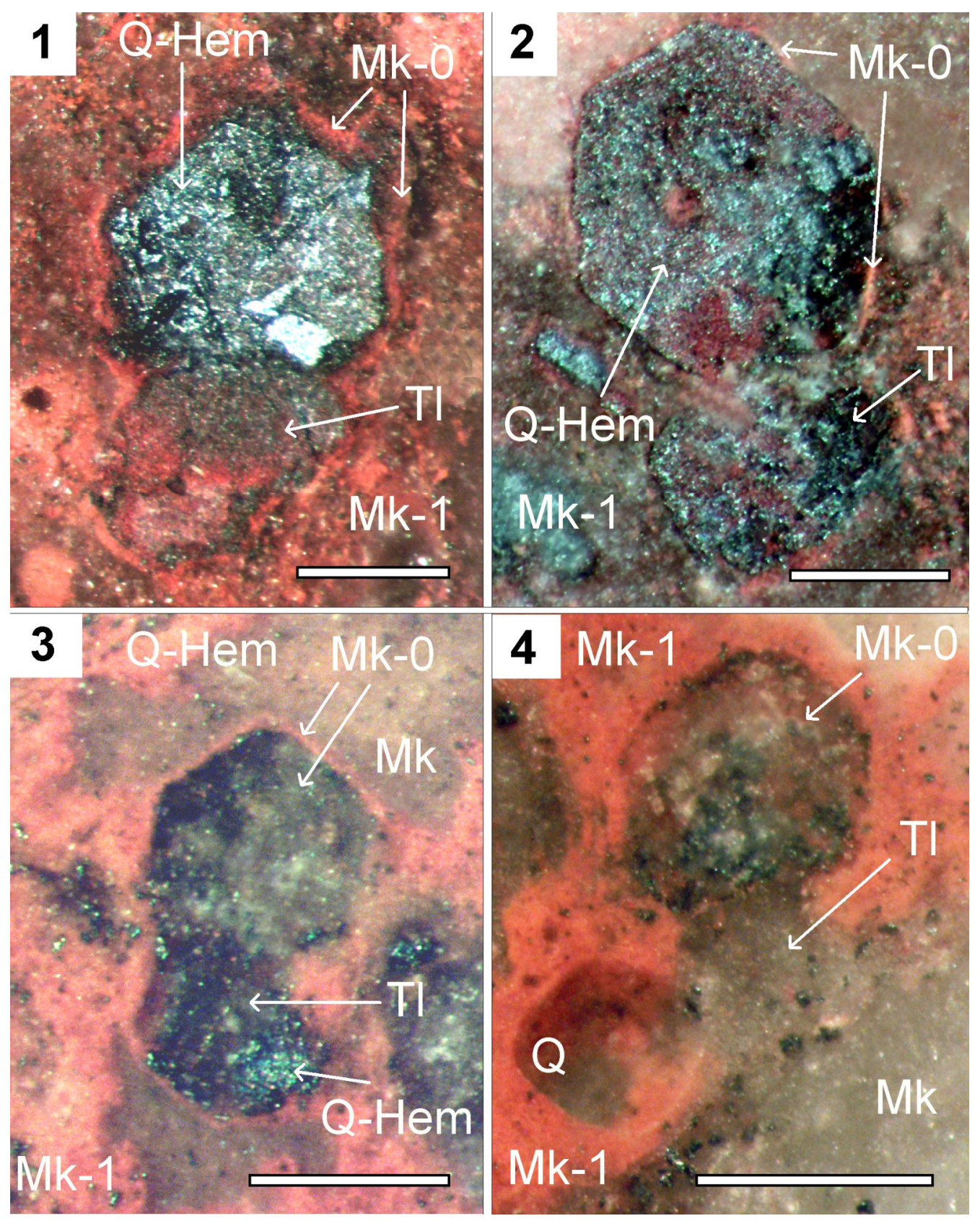

Рис. 5. Вирусоподобные структуры с «хвостами». Масштабная линейка - 0.5 мм. 
5.1. Крупная шестигранная VS в микрокварците (Mk-1), сложенная кварцгематитовым агрегатом, и вместе с мешковидным образованием (Tl), окруженная кремнистой оболочкой (Mk-0).

5.2. Крупная шестигранная VS в микрокварците (Mk-1), сложенная кварцгематитовым агрегатом, и вместе с мешковидным образованием (Tl), окруженная кремнистой оболочкой $(\mathrm{Mk}-0)$.

5.3. Средняя VS с «хвостом» (Tl) в микрокварцитах, сложенная более мелкозернистым микрокварцитом (Mk-0).

5.4. Средняя VS с «хвостом» (Tl) в микрокварцитах, сложенная более мелкозернистым микрокварцитом (Mk-0).

Крупные шестигранные VS в микрокварците Mk-1 (Рис. 5.1; 5.2) сложены кварцгематитовым агрегатом (Q-Hеm) с симплектитовой структурой, сформировавшегося, вероятно, при замещении вещества цитоплазмы. VS с мешковидными образованиями (Tl), окружены микрокварцитом (Mk-0), образовавшегося при замещении слизистых оболочек клеток.

Средние VS с «хвостами» (Tl) в микрокварцитах Mk-1 (Рис. 5.3; 5.4), сложены более мелкозернистым микрокварцитом (Mk-0) с редкими вкрапленниками-зернами гематита. Фрагмент «головки» D.h. наблюдается в непосредственном контакте с амебообразной структурой (Рис. 6.1). Возможно, это псевдоморфоза по остаткам белковой оболочки VS, внедрившейся в клетку амебы.
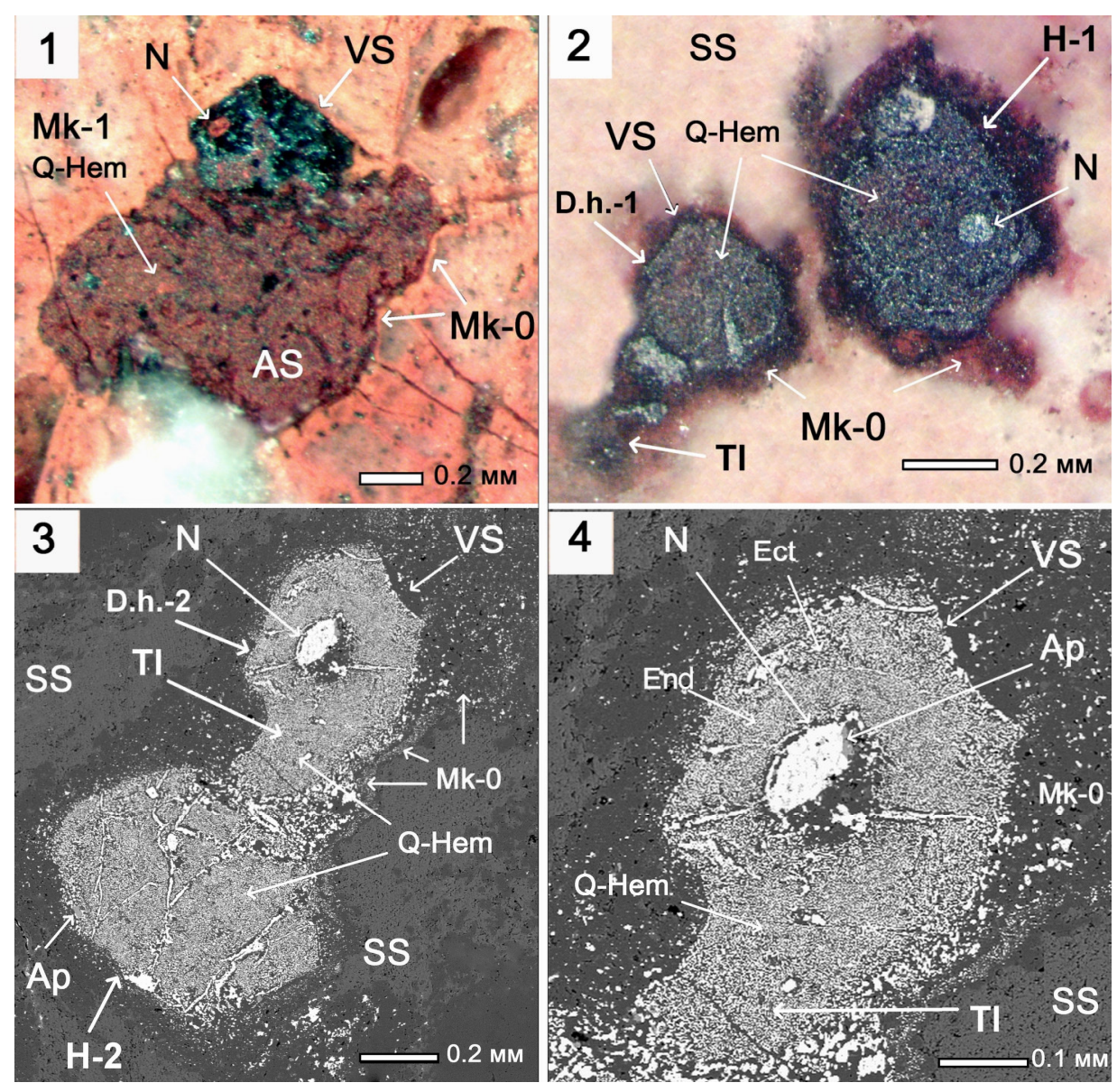
Рис. 6. Микрофоссилии вирусоподобной структуры Dinovirus hoglandi в микрокварцитах и в серицитовых сланцах. Масштабная линейка -0.2 мм.

6.1. Фрагмент «головки» Dinovirus hoglandi, замещенной кварцем и гематитом, в контакте с амебообразной структурой (AS), сложенной микрокварцитом с гематитом. Аншлиф.

6.2. Dinovirus hoglandi (D.h.-1) с «хвостом» (Tl), в «контакте» с шестигранной структурой Н-1. Обе структуры сложены кварц-гематитовым агрегатом и окружены кремнистой оболочкой. Структура Н-1 имеет округлое образование, подобное ядру, сложенное гематитом (Hеm). Прозрачно-полированный шлиф, без анализатора.

6.3. Dinovirus hoglandi (D.h.-2) с «хвостом» (Tl), в контакте с шестигранной структурой Н-2. Обе структуры сложены кварц-гематитовым агрегатом (Q-Hem) с симплектитовой структурой, и окружены микрокварцитом с редкими вкрапленниками гематита $(\mathrm{Mk}+\mathrm{Hem})$. В краю структуры H-2 призматическое зерно апатита. Микрофото прозрачно-полированного шлифа на растровом электронном микроскопе JSM-6510LA в обратноотраженных электронах.

6.4. Деталь внутреннего строения вирусоподобной структуры D.h.-2 с «хвостом» (Tl). В центре головки округлое образование, подобное ядру, окружено кварц-гематитовым агрегатом, сформировавшимся по эндоплазме (End) и эктоплазме (Ect) клетки. Ядро сложено гематитом и кварцем, между ними зерно апатита (Ap).

Вирусоподобные структуры Dinovirus hoglandi с образованиями подобными «Хвостам» встречаются также в серицитовых сланцах, и, в этих случаях, они сложены кварц-гематитовым агрегатом с симплектитовой структурой (Рис. 6.2; 6.3; 6.4). На фото прозрачно-полированного шлифа, без анализатора (Рис. 6.2) видно, что структура D.h.-1 с «Хвостом» (Tl) находится в тесном «контакте» с шестигранной «клеткой» Н-1. Обе структуры сложены кварц-гематитовым агрегатом и окружены общей кремнистой оболочкой (Mk-0). Шестигранная структура Н-1 имеет округлое образование, подобное ядру, сложенное гематитом (Неm).

На микрофотографии в обратноотраженных электронах на растровом электронном микроскопе JSM-7510LA видно, что D.h.-2 с «хвостом» (Tl), также находится в непосредственном контакте с шестигранной «клеткой» Н-2 (Рис. 6.3). Обе структуры сложены кварц-гематитовым агрегатом (Q-Hem) c симплектитовой структурой, и окружены общей оболочкой микрокварцита (Mk-0). Эта картина может быть интерпретирована как нападение вирусоподобной клетки-паразита на шестигранную клетку. В краю шестигранной «клетки» $\mathrm{H}-2$ находится призматическое зерно апатита (Рис. 6.3). В центре шестигранной головки D.h.-2 (возможно, это сечение белковой оболочки с икосаэдрической симметрией) имеется овальное образование подобное ядру, и вирусоподобная структура с «хвостом», очевидно, была эукариотом. Ядро сложено гематитом и кварцем и окружено кварц-гематитовым агрегатом, заместившим эндоплазму (End) и эктоплазму (Ect) клетки-вируса. В ядре между кварцем и гематитом находится зерно апатита (Ар) (Рис. 6.4).

5. Минеральные остатки нуклеозидфосфатов в микрофоссилиях эукариотов и вирусоподобных структур

Единство биологического мира определятся обязательным наличием у всех живых существ органических соединений фосфора - нуклеозидфосфатов, которые они должны были унаследовать у древних микроорганизмов. Однако достоверных вещественных свидетельств этому до сих пор не было выявлено. Зерна апатита, обнаруженные в 
минерализованной цитоплазме некоторых микрофоссилий эукариотов и вирусоподобных структур (Belyaev, Yukhalin, 2021), могли образоваться в процессах фоссилизации из остатков фосфорной кислоты распавшихся нуклеотидов АТФ, РНК и ДНК. При термальной силификации при температурах свыше ста градусов Цельсия вещество микроорганизмов - протоплазма, оболочки и мембраны, разлагались на воду, оксиды углерода и азота, которые в виде газовой фазы удалялись из области фоссилизации. При этом ионы кальция и фосфатные остатки, входившие в состав нуклеоздфосфатов АТФ, РНК и ДНК, оставались практически на месте окремнения (в пределах объема микрофоссилий). Фосфат-ионы и ионы кальция связывались с образованием апатита $\mathrm{Ca}_{5}$ $\left(\mathrm{PO}_{4}\right)_{3}$. У современных эукариотов АТФ содержит $18.5 \%$ фосфора, и, в среднем, составляет $0,04 \%$ от сырой массы клетки, а нуклеиновые кислоты содержат около $10 \%$ фосфора (Laura; et al., 2008). Таким образом, зная размеры зерен апатита, находящихся в ядрах и минерализованной цитоплазме микрофоссилий вирусоподобных структур и эукариотов, можно впервые приблизительно рассчитать массу первичного источника фосфора - древних нуклеозидфосфатов АТФ, РНК и ДНК (Belyaev, Yukhalin, 2021).

Зерно апатита в шестигранной клетке Н-2 (Рис. 7.3) с видимыми размерами: 13х25 мкм, скорее всего, является продольным сечением кристалла гексагональной призмы. Следует учитывать, что наблюдаемое сечение кристалла представляет собой частный случай и реальный размер зерна апатита может быть еще больше. Предполагаемый объем зерна апатита мог составлять около 10000 мкм $^{3}$, и, при плотности апатита 3.2 г/т, масса зерна составила бы 32000 пг, и содержала, соответственно, 6080 пг фосфора (апатит содержит 19\% фосфора). Источником этого фосфора могли служить, как распавшиеся нуклеозидфосфаты АТФ, так и ДНК и РНК генома. Расчетным путем можно приблизительно оценить, сколько фосфора могло приходиться на АТФ и на геном, содержащий ДНК и РНК.

Объем икосаэдра шестигранной клетки Н-2 около 60 миллионов мкм³. При плотности цитоплазмы близкой к плотности воды 1 пг/мкм ${ }^{3}$, клетка могла иметь массу около 60 миллионов пг. Если в клетке Н-2 (как и у современных клеток) содержалось бы 0,04\% АТФ, то его масса составила бы 24000 пг. АТФ содержит $18.5 \%$ фосфора, т.е., в клетке его могло содержаться 4500 пг. Но зерно апатита содержит 6080 пг фосфора, и, следовательно, остальные 1580 пг могли принадлежать ДНК и РНК генома клетки. Если при кристаллизации апатита в него входил фосфор из остатков фосфорной кислоты распавшихся ДНК и РНК, содержащих около 10\% фосфора, то масса последнего могла составить 15800 пг, или около $16200 \mathrm{~Gb}$ миллиардов пар оснований (нуклеотид массой в 1 пг содержит 978 миллионов пар оснований).

Зерно апатита в «ядре» D.h.-2 (Рис. 7.4) имеет размеры приблизительно 30х30х6 мкм, и объемом 5400 мкм $^{3}$. При плотности 3.2 г/ $\mathrm{cm}^{3}$ апатит содержит 19\% фосфора, т.е. 3200 пг. (1 пикограмм (пг) $=10^{-12}$ г). Однако источником для этого фосфора могли служить не только РНК и ДНК распавшегося генома, но и нуклеозидфосфат АТФ. Если предположить, что «головка» структуры D.h. имела симметрию икосаэдра, то ее объем составлял приблизительно 16 миллионов мкм ${ }^{3}$ (исключая объем «ядра» 1 млн мкм ${ }^{3}$ ). При плотности цитоплазмы клеток 1 пг/мкм ${ }^{3},\left(1\right.$ мкм $^{3}$ воды имеет массу 1 пикограмм $-10^{-12}$ г) масса «головки» структуры Dinovirus hoglandi могла быть равной 16 миллионам пг, и в цитоплазме клетки-вируса могло содержаться - 6400 пг АТФ. При содержании в АТФ 18.5\% фосфора, в цитоплазме клетки могло содержаться 1184 пг фосфора. Но зерно апатита содержит 3200 пг фосфора, и, следовательно, остальные 2020 пг могли принадлежать ДНК и РНК генома клетки. Следовательно, если апатит кристаллизовался из остатков фосфорной кислоты распавшегося генома ДНК и РНК, содержащих около 10\% фосфора, то масса последнего могла составить 20200 пг, или около $20600 \mathrm{~Gb}$ миллиардов 
пар оснований. Даже с учетом значительной погрешности, при вычислениях объема зерна апатита в ядре вирусоподобной клетки, величина генома может быть еще больше. Вопервых, истинные размеры зерна апатита могут значительно превышать размеры наблюдаемого сечения кристалла, и, во-вторых, в минералообразующей среде (ограниченной объемом клетки), может присутствовать некоторое количество рассеянного фосфора, который остался после окончания кристаллизации минерала.

Величина генома D.h. кажется нереально огромной. Для сравнения геном человека содержит $3.2 \mathrm{~Gb}$ пар оснований, а самый большой из известных живых организмов в настоящий момент геном амёбы Amoeba dubia $\mathrm{C}=670 \mathrm{~Gb}$ (в 200 раз больше, чем геном человека). По мнению некоторых исследователей, геномы эукариотов в процессе эволюции постепенно увеличивались за счет латерального трансгенного переноса вирусами фрагментов нуклеиновых кислот (Canchaya et al., 2003).

\section{6. Принцип геномно-ядерной пропорциональности}

Вместе с тем, величину генома клеток эукариотов можно оценить другим независимым способом. Так, в соответствии с моделью скелетной ДНК (Cavalier-Smith, 2005), объем ядер современных эукариотов определяется размерами ДНК и РНК, заключенных в ядре: чем больше величина (молекулярная масса) генома, тем больший размер ядра ему требуется. Т.е., зная объем ядра $\mathrm{V}^{\mathrm{N}}$ микрофоссилий эукариотов можно решить обратную задачу и косвенно определить величину (массу) генома С по формуле: $\mathrm{C}=\mathrm{V}^{\mathrm{N}} / \mathrm{Kc}$, где Кс коэффициент пропорциональности. Если предположить, что пропорциональность отношений между объемом ядра и величиной генома имеет физическую природу и унаследована одноклеточными эукариотами с самых ранних стадий их эволюции, тогда коэффициент пропорциональности можно вычислить по соотношению объемов ядер и масс геномов у современных одноклеточных эукариотов. Так, по литературным данным, для эукариотов с различной массой геномов: Amoeba proteus $(\mathrm{C}=290$ пг), Amoeba dubia $(\mathrm{C}=680$ пг) и дрожжей сахаромицетов Saccharomyces cerevisiae $\left(\mathrm{C}=1.2\right.$ пг) коэффициент пропорциональности Кс (отношение $\left.\mathrm{V}^{\mathrm{N}} / \mathrm{C}\right)$ в среднем составляет около 50.

Если для оценки величины генома D.h.-2 использовать принцип геномно-ядерной пропорциональности, то для объема ядра 1000000 мкм $^{3}$, при Кс $=50$, величина генома С составила бы 20000 пг, что практически совпадает с величиной 20200 пг, полученной при расчетах по апатиту.

Массы геномов в других микрофоссилиях вирусоподобных структур, а также у эукариотов: жгутиконосцев, фораминифер и многоклеточных микроорганизмов, оцененные как по включенным зернам апатита, так и по величине ядер, также составили десятки тысяч пикограмм (Belyaev, Yukhalin, 2021).

\section{7. Обсуждение результатов}

Для существования огромных геномов у древних вирусоподобных микроорганизмов были необходимы благоприятные эколого-геохимические обстановки и обилие биофильных элементов. Химический состав морских вод в Палеопротерозое, как и в современных морях и океанах, характеризовался низкими концентрациями калия и фосфора, которые ограничивают количественное и качественное развитие жизни. Содержание фосфат иона в морской воде является главным фактором, лимитирующим рост и размножение микроорганизмов (Delaney, et al. 1998; Diaz, 2008; Paytan, et al., 2007). Без фосфора невозможен синтез нуклеозидфосфатов и белков, т.е. жизнь вообще! В Палеопротерозое фосфор поступал в воду морских бассейнов преимущественно из широко распространенных на дне океанов толеитовых, существенно натриевых базальтов, тогда 
как в континентальных высококалиевых базальтах Гогланда содержание фосфора было выше более чем в три раза (Belyaev, 2018). Поэтому в Хогладскую эпоху вода моря Абеля могла быть существенно обогащена фосфат ионом.

Калий также является важнейшим биофильным химическим элементом, лимитирующим рост и размножение микроорганизмов. Он обеспечивает необходимое осмотическое давление в биологических жидкостях, и поддерживает электрический потенциал на мембранах клеток, сохраняя постоянство внутренней среды. Как было показано ранее (Беляев, 2013; Belyaev, 2018), воды внутриконтинентального моря были обогащены калием в пять и более раз, за счет флюидного воздействия высококалиевых базальтовых и гранитных магм.

Кроме того, радиоактивность морских вод более чем на $90 \%$ вызвана радиоактивным изотопом ${ }^{40} \mathrm{~K}$ с периодом полураспада $\mathrm{T}^{1 / 2}=1,3 \cdot 10^{9}$ лет. Содержание ${ }^{40} \mathrm{~K}$ в природной смеси изотопов 1640 миллионов лет тому назад было в 2.3 раза больше, чем в настоящее время, а концентрации его в морской воде были, по крайней мере, в пять раз больше. Поэтому, радиационный фон в морской воде в то время мог превышать современный на порядок. При этом, ${ }^{40} \mathrm{~K}$ концентрируется внутри клеток в непосредственной близости от ДНК и при его радиоактивном распаде $\beta$-частицы и $\gamma$ кванты ионизирующих излучений вызывают спонтанный мутагенез, во многом определяющий естественный отбор и новое видообразование.

Скопление фотосинтезирующего фитопланктона в слизистом веществе биопленок должно было приводить к значительному обогащению их свободным кислородом. Это косвенно подтверждается тем, что микрокварциты (Mk-1), сформировавшиеся при окремнении слизистого вещества биопленок, имеют характерный красновато-бурый цвет, за счет присутствия мельчайших примесей окислов железа. Кроме того, при фоссилизации и ожелезнении микроорганизмов эукариотов требовалось много свободного кислорода для окисления двухвалентного железа и формирования кварц-гематитового агрегата, содержащего до $30 \%$ гематита.

Таким образом, повышенные концентрации биогенных элементов калия, фосфора, оксидов углерода и азота, а также радиоактивного изотопа ${ }^{40} \mathrm{~K}$ в морской воде во время подводных извержений высоко калиевых магм, могли способствовать эволюционному развитию вирусоподобных эукариотов и многоклеточных микроорганизмов с огромными геномами.

Известно, что у всех живых организмов основная масса ДНК представлена некодирующими последовательностями. Например, некодирующие части генов в геноме человека составляют около 97\% от массы генома (Lander et al., 2001). Согласно модели Минкевича и Патрушева (Минкевич, Патрушев, 2007), некодирующие последовательности геномов эукариотов могут выполнять защитную (резервную) функцию от повреждаемых мутагенами нуклеотидов кодирующей части (Минкевич, Патрушев, 2007).

Огромные геномы древних микроорганизмов, также, скорее всего, содержали в основном некодирующие последовательности генов, и находились в постоянном контакте с эндогенными мутагенами, возникавшими в реакциях окисления-восстановления, при воздействии космического ионизирующего излучения, а также при распаде радиоактивного изотопа ${ }^{40}$ К. Свободные радикалы и потоки ионизирующего излучения постоянно повреждали геномные ДНК, и некодирующие последовательности генов могли играть роль резерва, защищающего жизнедеятельность клеток от воздействия мутагенов из окружающей среды.

Благоприятные эколого-геологические условия, связанные с внедрением высококалиевых гранитов комплекса рапакиви и поступлением в морскую воду 
гидротермальных флюидов с биофильными химическими элементами могли сохраняться достаточно долго. Так, Выборгский комплекс гранитов рапакиви с обнаженной площадью около двадцати тысяч квадратных километров и мощностью массива до десяти километров мог остывать в течение миллионов лет. При этом, по периферии БалтийскоЛадожского геоблока в течение внутриплитного гранитного магматизма эпохи Хогландия 1640-1500 миллионов лет продолжались процессы формирования двух десятков массивов гранитов рапакиви, которые сопровождались образованием вулканических и гидротермальных пород (Ларин, 2011). Все это время на территории геоблока, мог располагаться внутриконтинентальный морской бассейн, в котором сохранялись благоприятные эколого-геологические обстановки.

Однако после окончания эпохи Хогландия в юнжой части Балтийского щита, и прекращения поступления гидротермальных флюидов с биофильными химическими элементами, калий мог быть достаточно быстро исчерпан из морской воды глинистыми осадками, а фосфор поглощен микроорганизмами, и, после их отмирания, также депонирован в осадках на дне водоема. Это могло способствовать вымиранию древних планктонных микроорганизмов, или к их последующему эволюционному превращению, и приспособлению к среде, бедной биофильными элементами. Можно предположить, что благоприятные эколого-геохимические обстановки в континентальном море Абеля сыграли роль своеобразного трамплина в эволюции древнейших планктонных микроорганизмов.

Внутриплитный щелочной магматизм формации рапакиви имел локальный характер, но был проявлен в 35 комплексах на платформах всех континентов в интервале от 2800 до 500 миллионов лет (Ларин, 2011). В некоторых случаях он сопровождался формированием вулканических, гидротермальных и хемогенно-осадочных силикатных и карбонатных пород (Belyaev, 2018). Поэтому, благоприятные эколого-геологические условия, связанные с подводным высококалиевым гранитным магматизмом могли, подобно эпохе Хогландия, проявляться широко и значительное время, и в целом существенно повлиять на эволюцию биосферы Земли.

\section{Заключение}

Полученные данные позволяют предположить четвертый сценарий превращения древних вирусоподобных структур в облигатных паразитов. Эукариоты Dinoviridae incertae sedis являлись крупными факультативными клетками-паразитами, и могли размножаться путем деления. Они нападали на другие микроорганизмы, скорее всего, для поглощения их белков, АТФ и ДНК. При этом ДНК и РНК геномов клеток-паразитов вполне могли частично перемещаться в цитоплазму и попадать в ядро атакуемой клетки, в которой происходила репликация нуклеотидов вирусоподобных структур, и появлялись новые вирусные частицы. Со временем, в результате естественного отбора, процессы собственного деления клеток-паразитов утратили свое значение, и после их прекращения структуры превратились в вирусы - полноценные облигатные паразиты. Возможно, супергигантские вирусоподобные структуры из группы неясного систематического положения Dinoviridae Incertae sedis были представителями вымершего семейства одноклеточных факультативных паразитов, либо являлись предками гигантских вирусов семейства Mimiviridae. Вместе с вирусоподобными эукариотами уже существовали и древнейшие вирусы - облигатные сверхпаразиты, подобные вирофагам «Спутникам» мимивирусов. 


\section{Благодарности.}

Мы выражаем благодарность за техническую поддержку исследований: проф. Кривовичеву В. Г., проф. Прасолову Е. М., Галанкиной О. Л., Путинцевой Л. В., Кобылкову С. В. и его коллегам.

Литература

1. Беляев А. М. Петрология вулканитов формации рапакиви (о. Гогланд), //Региональная геология и металлогения, №55, 2013, с. 28-36.

2. Беляев А.М. Роль вирусов в эволюции ранней биосферы Земли //Геология, геоэкология, эволюционная география. Том XVI. СПб. 2017. с. 25-28.

3. Беляев А.М. Перспективы изучения микрофоссилий в вулканогенно-осадочных кремнистых породах Палеопротерозоя //Материалы LXIV сессии Палеонтологического общества, Изд. ПИН РАН, Москва, 2019, т.2. с. 28-43.

4. Беляев А.M. Палеовирусы //Материалы LXV сессии Палеонтологического общества, 2019, т.1. с. 28-31.

5. Беляев А.М. Юхалин П.В. Эволюция геномов эукариотов (по результатам изучения палеорпротерозойских микрофоссилий) //Материалы LXIV сессии Палеонтологического общества, 2020, с.18-21.

6. Беляев А.М., Юхалин П.В. Фосфатные останки нуклеотидов и размеры геномов микрофоссилий эукариотов из микрокварцитов Палеопротерозоя (остров Гогланд, Финский залив), 2021. Preprints.RU. https://doi.org/10.24108/preprints-3112213.

7. Ларин А.М. Граниты рапакиви и ассоциирующие породы, М., Наука, 2011, 403 с.

8. Минкевич, Л. И., Патрушев Л.И. Некодирующие последовательности генома и размер ядра эукариотической клетки как существенные факторы защиты генов от химических мутагенов //Биоорганическая химия, 2007, том 33, № 4, с. 474-477.

9. Abergel C., Legendre M., Claverie J.M. The rapidly expanding universe of giant viruses: Mimivirus, Pandoravirus, Pithovirus and Mollivirus. FEMS Microbiol. Rev. 2015; 39(6): pp. 779-96.

10. Arslan, D.; Legendre, M.; Seltzer, V.; Abergel, C.; Claverie, J.-M. (2011). Distant Mimivirus relative with a larger genome highlights the fundamental features of Megaviridae. Sciences. 2011. Vol. 108. No. 42, pp. 17486-17491. doi:10.1073/pnas.1110889108.

11. Belyaev A. M., Bogdanov Y.B., Levchenkov O.A. Petrogenesis of the bimodal rapakivi-related volcanites of the Island of Hogland, 1.64 Ga Wiborg batholith, Russia // International Field Conference: Proterozoic Granite System of the Penokean Terrane in Wisconsin, Madison, Wisconsin, USA, 1998, pp.139-140.

12. Belyaev A.M. Paleoproterozoic Underwater Volcanism and Microfossil-Like Structures in the Metasedimentary Siliceous Rocks (Hogland Island, Russia) // Journal of Earth Science, 2018; Vol. 29, No. 6, pp. 1431-1442, doi.org/10.1007/s12583-018-0883-4.

13. Belyaev A.M., Yukhalin P.V. Sizes of Genomes of Paleoproterozoic Microfossil Eukaryotes. Int. J. Paleobiol\&Paleontol 2021, 4(1): 000121. https://doi.org/10.23880\%2Fijpbp16000121 .

14. Belyaev A.M., Yukhalin P.V. Virus-Like Microfossils in the 1.64 Ga Siliceous Rocks From Hogland Island, Russia. PaleorXiv. DOI:10.31233/osf.io/n8zbu

15. Canchaya C., Fournous G., Chibani-Chennoufi S., et al. Phage as agents of lateral gene transfer. Curr. Opin. Microbiol, 2003, 6 (4): pp. 417-24. DOI: $10.1016 /$ S13695274(03)00086-9.

16. Cavalier-Smith, T. Economy, speed and size matter: evolutionary forces driving nuclear genome miniaturization and expansion. Ann. Bot. (Lond.) 2005, 95, pp. 147-175. 
17. Jônatas Abrahão et al., Tailed giant Tupanvirus possesses the most complete translational apparatus of the known virosphere/ Nature Communications 2018, volume 9, Article number: 749, doi:10.1038/s41467-018-03168-1.

18. Laidler, J. R., \& Stedman, K. M. Virus silicification under simulated hot spring conditions. Astrobiology, 2010; (6), pp. 569-576.

19. Legendre M., Arslan D., Abergel C., et al. Genomics of Megavirus and the elusive fourth domain of Life // Commun Integr Biol. 2012. B. 1. T. 5. pp. 102-106.

20. La Scola B., Desnues C., Pagnier I., The virophage as a unique parasite of the giant mimivirus // Nature. - 2008. - B.7209. - T. 455. - pp. 100-104. DOI: $10.1038 /$ nature07218 - PMID 18690211.

21. Paytan A., McLaughlin K. (2007) The Oceanic phosphorus cycle. Chemical Reviews 107(2): 563-576. 